\title{
Pandangan Syaykh Al-Zaytun A.S. Panji Gumilang Terhadap Pancasila Perspektif Fiqh Siyasah*
}

\author{
Pungki Harmoko, ${ }^{1}$ Siti Ngainnur Rohmah, ${ }^{2}$ \\ Institut Agama Islam Al Zaytun Indonesia \\ $d$ \\ 10.15408/sjsbs.v7i11.17791
}

\begin{abstract}
Pancasila as the ideology of the Indonesian people should become a spirit. In fact, he only became a mere jargon. The phenomena that occur are evidence, Bisexual, and Transgender, Gay, Lesbians (LGBT), corruption is rampant and has become a culture. God is only present in houses of worship but not present in daily activities. In other words, the concept of the precepts of Godhead fails to become the spirit of the nation. Automatic, the other precepts cannot be applied correctly. Shaykh Al-Zaytun (Grand Chancellor) Dr. (HC. MSU) U.S. Panji Gumilang has the view that Pancasila is a divine teaching. Not just jargon, but Pancasila can be applied well at Ma'had Az-Zaytun. Researchers tried to explore Shaykh's Al-Zaytun views on the Pancasila ideology through the book Al-Zaytun Sources of Inspiration (ASI). Then the view is associated with Siyasah Fiqh. After investigation, there is a relationship between Pancasila and Siyasah Dauliyah (international relations). This proves that the values contained in Pancasila are universal.
\end{abstract}

Keywords: Pancasila, Ideology, Siyasah Dauliyah

\begin{abstract}
Abstrak
Pancasila sebagai ideologi bangsa Indonesia seharusnya menjadi ruh.. Kenyataannya, ia hanya menjadi jargon belaka. Fenomena-fenomena yang terjadi merupakan bukti. Lesbian, Gay, Biseksual, dan Transgender (LGBT), korupsi yang merajalela dan menjadi budaya. Tuhan hanya hadir di rumah ibadah, namun tidak hadir dalam aktivitas keseharian. Dengan kata lain, konsep sila Ketuhanan Yang Maha Esa gagal menjadi ruh bangsa. Otomatis, sila yang lain tidak mampu diaplikasikan dengan benar. Syaykh Al-Zaytun (Grand Chancellor) Dr. (HC. MSU) A.S. Panji Gumilang memiliki pandangan bahwa Pancasila merupakan ajaran ilahi. Bukan hanya sekedar jargon, namun Pancasila mampu diaplikasikan dengan baik di Ma'had Al-Zaytun. Peneliti mencoba menggali pandangan Syaykh Al-Zaytun terhadap ideologi Pancasila melalui buku Al-Zaytun Sumber Inspirasi (ASI). Kemudian pandangan tersebut dikaitkan dengan Fiqih Siyasah. Setelah diteliti, ada relasi antara Pancasila dengan Siyasah Dauliyah (hubungan internasional). Hal ini membuktikan bahwa nilai-nilai yang terkandung dalam Pancasila bersifat universal.
\end{abstract}

Kata Kunci: Pancasila, Ideologi, Siyasah Dauliyah

* Received: July 3, 2020, Revision: July 28, 2020, Published: November 1, 2020.

${ }^{1}$ Pungki Harmoko adalah Peneliti pada Program Studi Hukum Tatanegara (Siyasah) Fakultas Syariah, Institut Agama Islam Al-Zaytun Indonesia, Email : ratnalangit1@gmail.com.

${ }^{2}$ Siti Ngainnur Rohmah adalah Dosen Institut Agama Islam Al Zaytun Indonesia, Mekarjaya, Gantar, Indramayu, Jawa Barat, alamat email: siti.ngainnur@iai-alzaytun.ac.id. 


\section{A. PENDAHULUAN}

Ideologi adalah landasan gerak manusia dalam melakukan perbuatan dan merupakan bentuk pilihan dan puncak dari tujuan manusia. Setiap manusia akan berkomunikasi dan bermasyarakat berdasarkan landasan ideologi yang dianutnya. Kecenderungan kepada ideologi merupakan hal yang penting karena manusia akan berusaha dan terus bersabar atas segala penderitaan dan kesulitan yang dihadapinya untuk sampai pada tujuan dan cita-cita ideologisnya. Bahkan manusia rela mengorbankan jiwa dan harta bendanya hingga nyawanya untuk menyebarkan ideologinya tersebut ${ }^{3}$.

Hanya dengan ideologi manusia dapat meyakini bahwa kehidupan ini bukan kumpulan dari pengulangan-pengulangan yang mengantarkan manusia kepada kekosongan, ketiadaan, kefanaan, dan sesuatu yang hampa. Hanya dengan ideologi kehidupan manusia menjadi bernilai dan dapat memanfaatkan secara benar kesempatan hidupnya di dunia. Dalam bingkai yang lebih luas, yakni suatu bangsa, ideologi sangat diperlukan. Sama halnya terhadap individu, tanpa adanya ideologi, suatu bangsa akan lemah dan secara perlahan akan hancur. Hal ini dikarenakan ideologi menjadi pandangan dan ideologi hidup bagi suatu bangsa ${ }^{4}$.

Pancasila sebagai ideologi merupakan cara pandang dan sistem berpikir yang dimiliki oleh bangsa Indonesia. Sukarno sebagai penggagas lahirnya Pancasila berharap bahwa Pancasila menjadi ruh. Bukan hanya sekedar jargon yang ada di dinding sekolah atau kantor-kantor instansi pemerintahan. Pancasila dengan nilai unidimensionalnya menjadi rujukan tingkah laku bangsa Indonesia.

Nilai pertama yang tercantum dari Pancasila adalah nilai ketuhanan. Yaitu nilai yang terkait dengan keterikatan individu dengan suatu hal yang dianggapnya mempunyai kemampuan sakral, suci, agung dan mulia. Nilai kedua adalah nilai kemanusiaan yaitu pembentukan satu kesadaran perihal kedisiplinan. Disiplin menjadi asas kehidupan, karena tiap-tiap manusia mempunyai kemampuan untuk jadi manusia prima, yakni manusia yang beradab. Ketiga, nilai persatuan yaitu paduan yang terdiri atas bagian-bagian, kehadiran Indonesia dan bangsanya di muka bumi ini bukan hanya untuk bersengketa. Namun bersatu untuk menciptakan kehidupan yang aman, damai dan tentram. Keempat, nilai permusyawaratan. Sebagai makhluk sosial, manusia memerlukan hidup berdampingan dengan orang lain. Di dalam interaksi itu umumnya terjadi kesepakatan, dan saling menghormati satu sama lain atas dasar tujuan dan keperluan bersama. Kelima, nilai keadilan yaitu nilai yang menjunjung norma menurut ketidak berpihakan, keseimbangan, dan pemerataan.

Nilai-nilai Pancasila yang begitu luhur dan agung sayangnya belum dapat terwujud dalam kehidupan berbangsa dan bernegara. Tuhan hanya hadir dalam rumah ibadah. Selepas itu Tuhan seakan absen dari rutinitas kehidupan sehari-hari hingga bangsa ini menjadi tidak beradab. Korupsi menjadi tradisi dan merupakan hal yang umum. Lesbian, gay, biseksual, dan transgender (LGBT), meskipun tidak

\footnotetext{
${ }^{3}$ A Fatih Syuhud, Menuju Kebangkitan Islam, (Malang: Pustaka Al-Khoirot, 2012), 66.

${ }^{4}$ Kaelan, Pendidikan Pancasila, (Yogyakarta: Paradigma, 2000), 196.
} 
dilegalkan namun fenomena yang terjadi semakin banyak penganutnya. Bangsa ini juga rentan untuk dipecah-belah, hanya karena perbedaan pendapat akan suatu permasalahan. Eksploitasi alam hanya dinikmati oleh segolongan kecil masyarakat tertentu dengan keuntungan besar yang dinikmati oleh asing. Tentu masih banyak lagi hal-hal yang bertentangan dengan nilai-nilai yang tercantum dalam Pancasila.

Pendiri dan pemimpin pesantren terpadu Ma'had Al-Zaytun adalah Syaykh (Grand Chancellor) Dr. (HC. MSU) A.S. Panji Gumilang, yang lahir di Gresik 30 Juli 1946. Pesantren Ma'had Al-Zaytun telah mampu mewujudkan nilai-nilai dari Pancasila. 'Pusat Pendidikan dan Pengembangan Budaya Toleransi dan Budaya Perdamaian' sebagai motto Ma'had Al-Zaytun bukan hanya sekedar simbol belaka. Motto tersebut dapat diaplikasikan di dalam kampus terpadu Ma'had Al-Zaytun. Toleransi terhadap umat beragama, baik yang seagama dan yang beragama lain sangat terjaga, sehingga tercipta kedamaian akibat toleransi yang diterapkan, khususnya di lingkungan kampus terpadu Ma'had Al-Zaytun.

Toleransi dan damai adalah bagian dari nilai-nilai Pancasila, terutama sila pertama. Sebagai salah satu bukti nyata wujud toleransi dan damai adalah diberikannya kesempatan umat nasrani untuk merayakan Natal di Wisma Tamu AlIshlah Ma'had Al-Zaytun. Sila pertama pada Pancasila dapat dijadikan dasar untuk lebih memudahkan dalam menjalankan sila-sila yang lainnya. Kesimpulannya, secara tidak langsung bahwa Al-Zaytun sebagai institusi pendidikan telah mampu mengaplikasikan Pancasila dalam perikehidupan sehari-hari.

Ideologi sebagai dasar dan arah dari pada negara, merupakan bagian dari objek kajian fiqih siyasah. Menurut Abdul Wahab Khallaf; objek kajian fiqh siyasah adalah penataan dan perundang-undangan yang dibutuhkan untuk mengatur negara sesuai dengan pokok-pokok ajaran agama, dengan tujuan mewujudkan kemaslahatan manusia serta memenuhi kebutuhan mereka ${ }^{5}$.

Ideologi Pancasila dan kaitannya dengan fiqih siyasah, merupakan konsep yang menarik menurut peneliti. Ideologi dalam bahasa arab merupakan istilah yang dapat diterjemahkan sebagai mabda'. Secara etimologis, mabda' adalah mashdar mimi dari bada'a (memulai), yabda'u (sedang memulai) dan bad'an (permulaan) dan mabda'an (titik permulaan). Secara terminologis adalah pemikiran mendasar yang dibangun di atas pemikiran-pemikiran (cabang) .

Nilai-nilai dari Pancasila sepenuhnya merupakan ajaran ilahi $^{7}$ adalah pemikiran Syaykh (Grand Chancellor) Dr. (HC. MSU) A.S. Panji Gumilang tentang ideologi. Pancasila sebagai sebuah konsep teoritis dan menjadi pemikiran mendasar

\footnotetext{
${ }^{5}$ Mujar Ibnu Syarif \& Khamami Zada, Fiqh Siyasah, (Jakarta: Erlangga, 2008), 10. Ahmad Sukardja, Hukum Tata Negara \& Hukum Administrasi Negara Dalam perspektif Figh Siyasah, (Jakarta: Sinar Grafika, 2012), 9. Abdul Wahab Khalaf, al siyasah syar'iyyah aw nidzham al dawlah al islamiyyah, (Al Kaherah: Dar al Anshar, 1977), 5.

6 Ahmad Athiyat, Jalan Baru Islam: Studi Tentang Transformasi dan Kebangkitan Umat, (Bogor: Pustaka Thariqul Izzah), 2004, 84.

${ }^{7}$ CH Robin Simanullang, Al-Zaytun Sumber Inspirasi, (Jakarta: Pustaka Tokoh Indonesia, 2015), 135.
} 
bangsa ini, telah mampu diaplikasikan di kampus terpadu Ma'had Al-Zaytun. Seorang aplikator ulung tentu memahami konsep yang diaplikasikannya secara mendalam. Bahwa menurut peneliti perlu digali lebih dalam relasi antara Pancasila sebagai weltanschauung bangsa Indonesia dan kaitannya dengan fiqh siyasah. Tentunya dengan menggali dari pencetus motto "Ajaran Ilahi untuk Semua", Syaykh Al-Zaytun (Grand Chancellor) Dr. (HC. MSU) A.S. Panji Gumilang. Hal ini sangat menarik, sebab di sisi lain ada yang menganggap bahwa Syaykh (Grand Chancellor) Dr. (HC. MSU) A.S. Panji Gumilang merupakan Imam Negara Islam Indonesia ${ }^{8}$. Merujuk dari beberapa hal yang telah dipaparkan di atas menjadi ketertarikan peneliti dengan mengambil judul: "Pandangan Syaykh Al-Zaytun A.S. Panji Gumilang Terhadap Pancasila Perspektif Fiqh Siyasah".

Tujuan penelitian merupakan jawaban atau sasaran yang ingin dicapai penulis dalam sebuah penelitian. Oleh sebab itu, tujuan penelitian ini adalah: Untuk mengetahui Ideologi Pancasila menurut pemikiran Syaykh Al-Zaytun A.S. Panji Gumilang. Untuk mengetahui kaitan Ideologi Pancasila dalam pemikiran Syaykh AlZaytun A.S. Panji Gumilang dengan fiqh siyasah.

\section{B. METODOLOGI PENELITIAN}

Penelitian ini adalah penelitian studi teks atau studi pustaka. Studi teks menurut Noeng Muhadjir meliputi: pertama, telaah teoritik suatu disiplin ilmu yang perlu dilanjutkan secara empirik untuk memperoleh kebenaran secara empirik pula. Kedua, studi yang berupaya mempelajari seluruh obyek penelitian secara filosofis atau teoritik dan terkait dengan validitas. Ketiga, studi yang berupaya mempelajari teoritik linguistik. Keempat, adalah studi karya sastra9. Adapun penelitian ini lebih dekat dengan jenis studi pustaka yang pertama dimana studi ini berusaha menelaah konsep ideologi Pancasila menurut pandangan Syaykh A.S. Panji Gumilang perspektif fiqh siyasah.

Adapun sumber dan jenis data yang digunakan dalam penelitian ini dikumpulkan dari sumber data sebagai berikut: Data primer: Sumber data primer adalah sumber pertama dimana sebuah data dihasilkan. Data primer dalam penelitian ini adalah buku Al-Zaytun Sumber Inspirasi (Simanullang). Data Sekunder: Data yang telah lebih dahulu dikumpulkan dan dilaporkan oleh orang di luar diri penyidik sendiri walaupun sesungguhnya data yang dikumpulkan asli. Dengan kata lain, data sekunder dapat diartikan sebagai data yang akan digali oleh penulis dari apa yang akan diterima oleh penulis secara tidak langsung, misalnya: melalui buku-buku Fiqih Siyasah (Dr A. Sudirman Abbas), Pancasila Ditinjau Dari Segi Yuridis Konstitusional dan Segi Filosofis (Fauzi), Negara Paripurna: Historisitas, Rasionalitas, dan Aktualitas Pancasila (Yudi Latif), Pancasila (Refleksi Komperehensif Hal-Ikhwal Pancasila) (Siswanto).

\footnotetext{
8 detik.com, 2011, https://m.detik.com/news/berita/d1627505/imam-nii-kw-9-panji-gumilangngumpet-karena-sudah-nikmati-hidup, diakses pada tanggal 12 Januari 2019 jam 11:33 wib.

${ }^{9}$ Noeng Muhadjir, “Metode Penelitian Kualitatif”, (Yogyakarta: Rake Paskin, 1996).
} 


\section{ANALISIS DAN PEMBAHASAN}

\section{Konsep Ideologi}

Ideologi berasal dari bahasa Yunani Idein, yang berarti melihat, atau idea, yang juga berarti raut muka, ide, perawakan, buah pikiran dan logia yang bermakna ajaran. Dengan kata lain ideologi adalah ajaran atau ilmu tentang ide dan buah pikiran (science des ideas $)^{10}$. Konsep ideologi muncul pertama kali di tengah dampak revolusi Perancis. Ia diciptakan oleh Antoine destut de Tracy pada tahun 1797, salah seorang kelompok filosof yang diberi tugas khusus oleh konvensi revolusi untuk menyebarkan ide pencerahan. De Tracy menulis Elements d'ideologi pada tahun 1801 dan 1815, mengusulkan sebuah ilmu pengetahuan baru tentang pikiran, yaitu idea-logy yang akan menjadi dasar bagi semua sains ${ }^{11}$.

\section{Jenis-jenis Ideologi}

Berdasarkan sistem pemikirannya, Frans Magniz membagi dua jenis ideologi yaitu ideologi tertutup dan ideologi terbuka ${ }^{12}$.

a. Ideologi tertutup. Ideologi tertutup mempunyai beberapa ciri khas. Ideologi tersebut merupakan ajaran atau pandangan dunia yang menentukan tujuan-tujuan dan norma-norma politik dan sosial yang ditasbihkan sebagai kebenaran mutlak yang tidak boleh dipersoalkan lagi. Bahwa atas nama ideologi tertutup dibenarkan pengorbanan-pengorbanan yang dibebankan kepada masyarakat. Selain itu isinya bukan hanya berupa nilai-nilai dan cita-cita tertentu, melainkan tuntutan-tuntutan konkret dan operasional yang keras yang diajukan dengan mutlak. Ciri khas ideologi tertutup adalah otoriter dan dijalankan secara totaliter, sehingga betapapun besarnya berbagai ideologi yang mungkin hidup dalam masyarakat itu, akan selalu mutlak bahwa orang harus selalu taat kepada ideologi tersebut. Itu juga berarti orang harus taat kepada elite yang mengembannya, taat terhadap tuntutan ideologi dan tuntutan itu mutlak dari nuraninya. Ideologi tertutup menuntut ketaatan tanpa reserve. Contoh dari ideologi tertutup adalah Marxisme-Leninisme yang meliputi ajaran dan paham tentang (a) hakikat realitas alam berupa ajaran materialisme dialektis dan ateisme; (b) ajaran makna sejarah sebagai materialisme historis; (c) norma-norma rigid bagaimana masyarakat harus ditata, bahkan bagaimana individu harus hidup; dan (d) legitimasi monopoli kekuasaan oleh sekelompok orang atas nama kaum proletar ${ }^{13}$.

$b$. Ideologi terbuka. Adapun ciri ideologi terbuka adalah bahwa nilai-nilai dan cita-citanya tidak dipaksakan dari luar, melainkan digali dan diambil dari harta kekayaan rohani, moral dan budaya masyarakat itu sendiri. Dengan demikian ia merupakan hasil musyawarah dan konsensus dari masyarakat tersebut. Ideologi terbuka tidak diciptakan oleh negara melainkan digali dan ditemukan dalam

\footnotetext{
${ }^{10}$ Kaelan, Pendidikan Pancasila, (Yogyakarta: Paradigma, 2000), 60-61.

11 Kaelan, Negara Kebangsaan Pancasila: Kultural, Historis, Filosofis, Yuridis dan Aktualisasinya, (Yogyakarta: Paradigma, 2013), 113.

12 AL Marsudi Subandi, Pancasila dan UUD 45 dalam Paradigma Reformasi, (Jakarta: PT. Raja Grafindo Persada, 2001), 57.

${ }^{13}$ Franz Magnis Suseno, Filsafat Sebagai Ilmu Kritis, (Yogyakarta: Kanisius, 1992), 232-233.
} 
masyarakat itu sendiri. Dengan kata lain ideologi terbuka adalah milik seluruh rakyat dan masyarakat, bersifat inklusif, tidak totaliter dan tidak dapat dipakai melegitimasi kekuasaan sekelompok orang.

\section{Sejarah Pancasila}

Sebagai kristalisasi nilai-nilai dan pandangan hidup, tentu benih-benih pancasila telah ada dan hidup dalam alam pikiran dan tindakan bangsa ini beratusratus tahun lamanya sebelum bangsa ini mendeklarasikan kemerdekaannya. Sebelum pengaruh agama-agama datang, masyarakat Indonesia telah bersikap religiusspiritual yang kita kenal dengan penganut animisme dan dinamisme. Animisme dan dinamisme merupakan budaya religius pertama bangsa Indonesia. Pada lintasan sejarah ini, Tuhan telah menyejarah dalam ruang publik Nusantara. Agama (dapat kita artikan konsep religiusitas) mempunyai peran utama dalam pendefinisian insititusi-institusi sosial. Penguasa menghormati otoritas kegamaan sebagai bagian dari ketundukannya kepada Tuhan ${ }^{14}$.

Zaman Kerajaan Kutai telah mengenal dan menemukan nilai-nilai, seperti nilai sosial politik, dan Ketuhanan dalam bentuk kerajaan, kenduri dan sedekah kepada para Brahmana. Hal ini terkait dengan nilai-nilai integrasi sosial, kebersamaan, serta nilai ketuhanan ${ }^{15}$.

Pada masa Kerajaan Sriwijaya telah dikenalkan nilai-nilai maupun pandangan pandangan tentang dasar kesatuan, yakni kerajaan. Nilai-nilai ini mengeksplisitkan serta memberi bahan-bahan material terhadap nilai-nilai Pancasila, seperti nilai persatuan yang tidak terpisahkan dengan nilai ke-Tuhanan. Dalam nilai ini, raja dianggap merupakan pusat kekuasaan dan kekuatan religius yang berusaha mempertahankan kewibawaannya terhadap para datu (raja-raja kecil). Selain itu selama kekuasaan Sriwijaya, nilai-nilai kemasyarakatan dan ekonomi juga telah mengemuka dan terjalin satu sama lain dengan nilai internasionalisme dalam bentuk hubungan dagang yang terentang dari pedalaman sampai ke negeri-negeri seberang lautan pelabuhan kerajaan dan Selat Malaka yang diamankan oleh para nomad laut yang menjadi bagian dari birokrasi pemerintahan Sriwijaya ${ }^{16}$.

Di bawah pemerintahan Prabu Hayam Wuruk, Gajah Mada telah berhasil mengintegrasikan nusantara. Semboyan dan Istilah-istilah seperti Bhinneka Tunggal Ika, Nusantara, Pancasila sudah ada pada periode ini. Tiga istilah ini konon telah terdapat dan termuat dalam Kakawin Nagarakertagama karangan empu Prapanca dan buku Sutasoma karangan Empu Tantular, meski dengan pengertian dan pemaknaan sedikit berbeda. Sebagai contoh, dalam buku tersebut istilah Pancasila di samping mempunyai arti "berbatu sendi yang lima" (dalam bahasa Sansekerta), juga

14 Yudi Latif, Negara Paripurna: Historisitas, Rasionalitas dan Aktualitas Pancasila, (Jakarta: PT. Gramedia Pustaka Utama, 2011), 58-59.

15 Kaelan, Pendidikan Pancasila, 29.

${ }^{16}$ Suwarno, Pancasila Budaya dan Bangsa, (Yogyakarta: Kanisius, 1993), 20-21. 
mempunyai arti "pelaksanaan kesusilaan yang lima" (Pancasila Krama), yaitu: 1) Tidak boleh melakukan kekerasan. 2) Tidak boleh mencuri. 3) Tidak boleh berjiwa dengki. 4) Tidak boleh berbohong. 5) Tidak boleh mabuk minuman keras ${ }^{17}$.

Masa kerajaan Islam, dengan Islam sebagai agama, telah mulai dipeluk oleh banyak Kerajaan-kerajaan di Nusantara. Tentu agama ini telah banyak memberi sumbangsih bagi terbentuknya pandangan dunia baru bagi masyarakat Nusantara. Dengan karakter egaliter, yakni menampik stratifikasi kasta di masa lalu, Islam telah memberi daya dorong terbentuknya masyarakat religius baru dengan penekanan pada nilai-nilai kesamaan yang merupakan hak yang melekat pada diri manusia. Konsep kesatuan ummah, juga telah menyorongkan konsep baru bernama persatuan. Dengan kesamaan identitas agama mereka, kerajaan-kerajaan di nusantara seperti Kerajaan Samudera Pasai di Sumatera, Kesultanan Islam Aceh, Kerjaaan Demak, Kerajaan Pajang, Kesultanan Mataram, Kerajaan Banten, Kerajaan Ternate, Tidore, Bacan, Kerajaan Jailolo, dan Kerajaan Goa Makasar, serta lainnya-semakin intensif untuk menjalin kerjasama mereka dalam mengusir penjajah Belanda, yang telah merebut hak kekuasaan sosial, teritori, ekonomi, maupun politik di wilayah masingmasing.

Pergulatan ide-ide kebangsaan Indonesia tersebut selanjutnya telah menciptakan monumen kebangsaan bernama: Sumpah pemuda (28 Oktober 1928). Mereka para pemuda-pemudi Indonesia menyatakan:

"Kami putra dan putri Indonesia mengaku bertumpah darah yang satu, tanah air Indonesia; Kami putra dan putri Indonesia mengaku berbangsa yang satu, bangsa Indonesia; Kami putra dan putri Indonesia menjunjung bahasa persatuan, bahasa Indonesia".

Puncaknya adalah dengan dikemukakannya philosofische grond-slag oleh Soekarno tanggal 1 Juni 1945, pada sidang BPUPKI. Ada 5 hal yang dikemukakan oleh Soekarno, yaitu: Kebangsaan Indonesia, Perikemanusiaan/ Internasionalisme, Mufakat/ Demokrasi, Kesejahteraan Sosial dan Ketuhanan yang Berkebudayaan ${ }^{18}$. Lima hal yang disampaikan oleh Soekarno ini kemudian termaktub dalam alinea keempat Pembukaan Undang-Undang Dasar Negara Indonesia 1945, yang kemudian diberi nama Pancasila ${ }^{19}$.

\section{Pengertian Fiqh Siyasah}

Istilah Figh Siyasah merupakan kalimat majemuk yang terdiri dari dua kata, yakni figh dan siyasah. Secara etimologis, Fiqh berarti pemahaman yang mendalam dan akurat sehingga dapat memahami tujuan ucapan dan atau tindakan tertentu. Sedangkan secara terminologis, fiqh lebih populer di definisikan sebagai berikut: Ilmu

${ }^{17}$ Darmodihardjo, Orientasi Singkat Pancasila, (Jakarta: Gita Karya, 1978), 6.

18 Yudi Latif, Negara Paripurna: Historisitas, Rasionalitas dan Aktualitas Pancasila, (Jakarta: PT. Gramedia Pustaka Utama, 2011), 15-17.

19 Soekarno, Pancasila sebagai Dasar Negara, (Jakarta: Inti Idayu Press dan Yayasan Pendidikan Soekarno, 1984), 154. 
tentang hukum-hukum syara' yang bersifat perbuatan yang dipahami dari dalil dalilnya yang rinci. Sementara mengenai asal kata Siyasah terdapat dua pendapat. Pertama, sebagaimana dianut al-Maqrizy menyatakan, Siyasah berasal dari bahasa mongol, yakni dari kata Yasah yang mendapat imbuhan huruf sin berbaris kasrah di awalnya sehingga di baca Siyasah. Pendapat tersebut di dasarkan kepada sebuah kitab undang-undang milik Jengish Khan yang berjudul Ilyasa yang berisi panduan pengelolaan Negara dengan berbagai bentuk hukuman berat bagi pelaku tindak pidana tertentu. Kedua, sebagaimana di anut Ibn Taghri Birdi, Siyasah berasal dari campuran tiga bahasa, yakni bahasa Persia, turki dan mongol. Ketiga, semisal dianut Ibnu manzhur menyatakan, Siyasah berasal dari bahasa arab, kata sasa-yasususiyasatun ${ }^{20}$, yang semula berarti mengatur, memelihara, atau melatih binatang, khususnya kuda. Sejalan dengan makna yang disebut terakhir ini, seseorang yang profesinya sebagai pemelihara kuda. Sedangkan secara terminologis banyak definisi Siyasah yang di kemukakan oleh para yuridis Islam. Menurut Abu al-Wafa Ibn 'Aqil, Siyasah adalah sebagai berikut: "Siyasah berarti suatu tindakan yang dapat mengantar rakyat lebih dekat kepada kemaslahatan dan lebih jauh dari kerusakan, kendati pun Rasulullah tidak menetapkannya dan Allah juga tidak menurunkan wahyu untuk mengaturnya." Dalam redaksi yang berbeda Husain Fauzy al-Najjar mendefinisikan Siyasah sebagai berikut:

"Siyasah berarti pengaturan kepentingan dan pemeliharaan kemaslahatan rakyat, serta pengambilan kebijakan demi menjamin terciptanya kebaikan bagi mereka. Dan definisi yang paling ringkas dari Ibn Manzhur tentang siyasah adalah "mengatur sesuatu dengan cara yang membawa kepada kemaslahatan."Setelah diuraikan definisi fiqh dan Siyasah, baik secara etimologis maupun terminologis, perlu juga kiranya dikemukakan definisi fiqh Siyasah. Penting dicatat, di kalangan teoritisi politik Islam, ilmu fiqh Siyasah itu sering juga di sinonimkan dengan ilmu Siyasah Syar'iyyah. Sebagaimana dijelaskan di atas dapat disimpulkan, fiqh Siyasah adalah ilmu tata Negara Islam yang secara spesifik membahas tentang seluk beluk pengaturan kepentingan ummat manusia pada umumnya dan Negara pada khususnya, berupa penetapan hukum, peraturan, dan kebijakan oleh pemegang kekuasaan yang bernafaskan atau sejalan dengan ajaran Islam. Hal ini guna mewujudkan kemaslahatan bagi manusia dan menghadirkannya dari berbagai kemudaratan yang mungkin timbul dalam keidupan bermasyarakat, berbangsa, dan bernegara yang dijalaninya.

\section{Cakupan Fiqh Siyasah}

Para ulama berbeda pendapat dalam menentukan ruang lingkup kajian fiqh siyasah. Di antaranya ada yang menetapkan lima bidang, namun ada pula yang menetapkan kepada empat atau tiga bidang pembahasan. Bahkan ada sebagian ulama yang membagi ruang lingkup kajian fiqh Siyasah menjadi beberapa bidang. Menurut al-Mawardi dalam Al-Ahkam Al-Sulthaniyah, ruang lingkup kajian fiqh Siyasah mencakup: a) Kebijaksanaan pemerintah tentang peraturan perundang-undangan (siyasah dusturiyah). b) Ekonomi (siyasah maliyah). c) Peradilan (siyasah qadha'iyah). d)

${ }^{20}$ Ibn Manzur, Lisan al-'Arab, (Beirut: Dar El-Shadir, 1986), 108. 
Hukum perang (siyasah harbiah). e) Administrasi negara (siyasah idariyah). Sedangkn ibnu Taimiyah dalam "al-siyasah al syar'iyah fi ishalah al-ra'i wa al-ra'iyah" meringkasnya menjadi empat bidang kajian yaitu: a) Peradilan. b) Administrasi Negara. c) Moneter. d) Serta hubungan internasional (siyasah dauliyah).

Sementara Abdul wahhab khallaf lebih mempersempitnya menjadi tiga bidang kajian saja ${ }^{21}$, yaitu: a) Siyasah Dusturiyyah Syar'iyyah. b) Siyasah Maliyah Syar'iyyah. c) Siyasah Khorijiyyah/Dauliyyah Syar'iyyah. Berbeda dengan tiga pemikiran di atas, Hasbi Ash-Shiddieqy membagi ruang lingkup fiqh siyasah menjadi delapan bidang22, yaitu: a) Politik pembuatan perundang-undangan. b) Politik. c) Politik peradilan. d) Politik moneter/ekonomi. e) Politik administrasi. f) Politik hubungan internasional. g) Politik pelaksanaan perundang-undangan. h) Politik peperangan.

\section{Pancasila Menurut Pandangan Syaykh Al-Zaytun A.S. Panji Gumilang}

Bagi Negara Republik Indonesia yang menjadi sumber dari sumber hukum adalah Pancasila, yang dijumpai dalam alinea keempat Pembukaan Undang-undang Negara Republik Indonesia Tahun 1945. Pancasila sebagai dasar ideologi, pandangan hidup, dasar negara, dan sumber tertib hukum Indonesia yang menjiwai serta menjadi mercusuar hukum Indonesia. Masuknya intuisi-religi sebagai tata cara dalam ilmu hukum Indonesia diharapkan mampu menjadikan lengkap ilmu hukum dan memberi semangat serta jiwa pembangunan hukum Indonesia ${ }^{23}$. "Atas berkat rahmat Allah Yang Maha Kuasa dan dengan didorongkan oleh keinginan luhur, supaya berkehidupan kebangsaan yang bebas, maka rakyat Indonesia menyatakan dengan ini kemerdekaannya." (Alinea ke-3 Pembukaan Undang-Undang Dasar 1945).

Proses panjang perjalanan sejarah perjuangan bangsa yang terjajah selama kurang lebih 350 tahun, mengantarkan Indonesia kepada kemerdekaan. Para pendiri bangsa menyadari bahwa ada campur tangan Tuhan dalam segala hal, termasuk kemerdekaan bangsa ini. Bukti otentik tersebut termaktub dalam alinea ke-3 pembukaan Undang-undang Dasar Negara Indonesia 1945. Begitu pula dengan terpilihnya Indonesia sebagai sebuah identitas yang dikenal dunia, yang juga merupakan karunia Ilahi. Hal ini yang menjadi landasan bahwa Indonesia merupakan negara karunia Ilahi ${ }^{24}$. Indonesia sebagai negara karunia Ilahi disampaikan oleh Syaykh Al-Zaytun, Dr. AS Panji Gumilang pada taushiyah peringatan 1 Muharram 1429 H di Ma'had Al-Zaytun.

Selaras dengan negara karunia Ilahi, Pancasila sebagai dasar Negara dan sumber dari segala sumber hukum merupakan ajaran Ilahi. Pokok pemikiran utama Syaykh Al-Zaytun Dr. AS Panji Gumilang ini kurang lebih sama dengan pemikiran

\footnotetext{
${ }^{21}$ Ahmad Sudirman Abbas, Fiqh Siyasah, (Depok: Abbas Press, 2015), 6.

${ }^{22}$ Ahmad Sudirman Abbas, Figh Siyasah, 6.

${ }^{23}$ Abdul Ghofar al-Anshori, Penerapan Prinsip Syari'ah dalam Lembaga Pembiayaan dan Perusahaan Pembiayaan, (Yogyakarta:Pustaka Pelajar, 008), 5.

$24 \mathrm{CH}$ Robin Simanullang, Al-Zaytun Sumber Inspirasi, 133.
} 
Soekarno tentang Pancasila. Dalam uraiannya mengenai prinsip Ketuhanan, Soekarno berkata:

Bukan saja bangsa Indonesia ber-Tuhan, tetapi masing-masing orang Indonesia hendaknya ber-Tuhan. Tuhannya sendiri. Yang Kristen menyembah Tuhan menurut petunjuk Isa al-Masih, yang Islam menurut petunjuk Nabi Muhammad Shallallahu ‘alaihi wassalam. Orang Budha menjalankan ibadahnya menurut kitab-kitab yang ada padanya. Tetapi marilah kita ber-Tuhan. Hendaknya Negara Indonesia ialah negara yang tiap-tiap orangnya dapat menyembah Tuhannya dengan cara yang leluasa. Segenap rakyat hendaknya ber-Tuhan secara kebudayaan. Yakni dengan tiada egoisme-agama. Dan, hendaknya Negara Indonesia satu Negara yang bertuhan!25.

Pancasila sebagai sumber hukum yang berdasarkan ajaran Ilahi ${ }^{26}$ (Tribunkaltim.com 2011), selain diyakini sebagai pandangan hidup, wajib untuk ditaati oleh seluruh elemen masyarakat juga harus menjadi ruh bangsa ini. Ia merupakan hasil ijtihad Founding Father bangsa ini. Intisari dari nilai agama, dan budaya mengkristal dalam wujud Pancasila.

Hukum telah menjadi ruh masyarakat Islam dalam bingkai figh siyasah. Sebagaimana tercatat dalam sejarah, Imran bin al-Husain al-Khunza menceritakan bahwa ada seorang wanita dari Juhainah yang datang kepada Rasulullah Shollallahu 'alaihi Wasallam dalam keadaan hamil karena berzina. Ia datang berhukum kepada Rasulullah. Mentalitas cinta dan patuh terhadap hukum telah menjadi akidah yang tertanam di dalam jiwanya (Siregar 2019).

\section{Pokok-pokok pemikiran Syaykh Al-Zaytun Dr. AS Panji Gumilang mengenai Pancasila}

Pertama, Sila Ketuhanan Yang Maha Esa; a) Negara Indonesia adalah negara karunia Ilahi ${ }^{27}$. b) Negara sebuah wahana ibadah/ dharma bakti/ pengabdian ${ }^{28}$. c) Maknanya: mewujudkan masyarakat yang beketuhanan, yakni masyarakat yang anggotanya dijiwai oleh semangat mencapai ridlo Tuhan (Mardlatillah), berbuat baik kepada seluruh manusia dan seluruh mahluk ${ }^{29}$. d) Kayanya makna agama jika pemeluknya cenderung pada aspek kemanusiaan daripada aspek teologis ${ }^{30}$. e) Hilangnya toleransi menimbulkan konflik ${ }^{31}$. Dialog keagamaan diperlukan tidak hanya dikalangan elit-elit tertentu namun juga pada masyarakat. f) Manusia yang adil adalah manusia yang beragama, apapun agamanya ${ }^{32}$.

25 Yudi Latif, Negara Kebangsaan Pancasila: Kultural, Historis, Filosofis, Yuridis dan Aktualisasinya, (Paradigma: 2013), 74.

26 Tribunkaltim.com. Juni 14, 2011. https://kaltim.tribunnews/2011/06/14/panji-gumilangpancasila-itu-ajaran-ilahi, diakses pada tanggal 14 Januari 2019 jam 11:45 wib

27 CH Robin Simanullang, Al-Zaytun Sumber Inspirasi, 145.

28 CH Robin Simanullang, Al-Zaytun Sumber Inspirasi, 144.

${ }^{29} \mathrm{CH}$ Robin Simanullang, Al-Zaytun Sumber Inspirasi, 147.

30 CH Robin Simanullang, Al-Zaytun Sumber Inspirasi, 148.

31 CH Robin Simanullang, Al-Zaytun Sumber Inspirasi, 149.

32 dutanews. February 9, 2019. https://www.doetaindonesia.com/persatuan-indonesia-terancamsyaykh-panji-ajak-kembali-ke-jatidiri-bangsa-yang-hakiki/, diakses pada tanggal 14 Januari 2019, jam 12:30. 
Kedua, Sila Kemanusiaan yang Adil dan Beradab; a) Manusia yang sempurna adalah yang adil dan beradab ${ }^{33}$. b) Kemanusiaan lebih tinggi dari agama. c) Adil terhadap diri sendiri dan condong kepada kebenaran. d) Beradab bermakna mempunyai ahlak dan moralitas, kemajuan lahir dan bathin. e) Manusia yang berperadaban tentunya lebih mudah menerima kebenaran dengan tulus, dan lebih mungkin untuk mengikuti tata cara dan pola kehidupan masyarakat yang teratur, yang mengenal hukum. Hidup dengan hukum dan peraturan adalah ciri masyarakat berperadaban dan berkebudayaan. f) Kemanusiaan yang adil dan beradab bermakna jujur, semangat mempersiapkan generasi penerus, sadar akan keteraturan, menimbulkan semangat universal yang mewujudkan sikap bahwa semua bangsa dapat dan harus hidup dalam harmoni penuh toleransi dan damai, berbakti tanpa mementingkan diri sendiri demi kebaikan bersama, suatu sikap revitalisasi diri, untuk memupuk dinamisme kreatif kehidupan, yang menghantarkan seseorang menjadi selalu dinamis, selalu sensitif dan peka pada gerak perubahan dan pembaharuan.

Ketiga, Sila Persatuan Indonesia; a) Persatuan Indonesia adalah suatu landasan hidup bangsa atau sistem yang selalu mementingkan silaturahim, kesetiakawanan, kesetiaan, dan keberanian. b) Indonesia wujud dan hidup untuk mewujudkan kasih sayang sesama bangsa maupun antar bangsa ${ }^{34}$. c) Memantapkan ciri-ciri unik sebuah masyarakat bangsa, yakni masyarakat bangsa yang sadar terhadap tanggung jawab global, bersatu dalam mewujudkan persatuan universal ${ }^{35}$. d) Persatuan Indonesia adalah fitrah. Fitrah manusia yang interdependen, bergerak membangun dalam wadah negara. e) Negara kebangsaan adalah anugerah Tuhan. Kewajiban dan kepentingan seluruh warga negara untuk menjaga persatuan Indonesia.

Keempat, Sila Kerakyatan yang dipimpin oleh hikmah kebijaksanaan dalam permusyawaratan/perwakilan; a) Dasar ini mengandung makna perwujudan republik dan demokrasi, yang senantiasa praktis bukan teoritis yang dibimbing oleh hikmah kebijaksanaan berbentuk kepintaran dan kemampuan mencapai hasil menyusun rencana yang benar untuk mencapai dan memperoleh hasil yang dikehendaki ${ }^{36}$. b) Hikmat kebijaksanaan yang menjadi pimpinan kerakyatan dan permusyawaratan adalah segala sesuatu yang dikumpulkan dari pengetahuan tentang jalan-jalan Allah Tuhan YME dan menerapkannya dalam hidup sehari-hari. c) Kerakyatan yang dipimpin oleh hikmah kebijaksanaan adalah kerakyatan yang dipimpin oleh pendidikan yang mumpuni. d) Hikmah kebijaksanaan atau pendidikan akan mewarnai kerakyatan yang penuh harmoni, toleransi dan damai, jauh daripada sikap radikalisme apalagi terorisme.

Kelima, Sila Keadilan Sosial bagi Seluruh Rakyat Indonesia; a) Mewujudkan suatu keadilan sosial bagi seluruh rakyat Indonesia adalah merupakan

\footnotetext{
${ }^{33} \mathrm{CH}$ Robin Simanullang, Al-Zaytun Sumber Inspiras, 150.

${ }^{34} \mathrm{CH}$ Robin Simanullang, Al-Zaytun Sumber Inspirasi, 153.

${ }^{35} \mathrm{CH}$ Robin Simanullang, Al-Zaytun Sumber Inspirasi, 154.

${ }^{36} \mathrm{CH}$ Robin Simanullang, Al-Zaytun Sumber Inspirasi, 155.
} 
tujuan dari cita-cita bernegara dan berbangsa, menyangkut keilmuan, keikhlasan pemikiran, dan kelapangan hati. b) peradaban, kesejahteraan keluarga, keadilan masyarakat dan kedamaian. c) Mewujudkan suatu keadilan sosial, juga berarti mewujudkan azas masyarakat yang stabil yang ditumbuhkan oleh warga masyarakat itu sendiri. d) Keadilan sosial memimpin bangsa dan negara ke dalam keadilan dan kebenaran sehingga semua rakyat Indonesia mengetahuinya, melakukannya, dan hidup di dalamnya dan mentaatinya ${ }^{37}$. e) Demokrasi Indonesia bertujuan untuk mewujudkan keadilan sosial bagi seluruh rakyat Indonesia ${ }^{38}$.

\section{Kaitan Ideologi Pancasila Menurut Syaykh Al-Zaytun A.S. Panji Gumilang dengan Fiqh Siyasah}

Nilai-nilai yang tercantum pada Pancasila dalam pemikiran Syaykh Al-Zaytun A.S. Panji Gumilang kurang lebih sama dengan dasar-dasar siyasah dauliyah pada fiqh siyasah. Dasar-dasar yang digunakan sebagai landasan para ulama di dalam siyasah dauliyah dan dijadikan ukuran apakah siyasah dauliyah berjalan sesuai dengan semagat Islam atau tidak. Ada delapan dasar-dasar dalam siyasah dauliyah dan hubungannya dengan nilai-nilai Pancasila menurut Syaykh Al-Zaytun A.S. Panji Gumilang, digambarkan pada tabel berikut:

\begin{tabular}{|c|c|}
\hline $\begin{array}{l}\text { Dasar-dasar dalam } \\
\text { Siyasah Dauliyah }\end{array}$ & Pancasila Menurut Syaykh Al-Zaytun \\
\hline $\begin{array}{l}\text { Kesatuan Umat } \\
\text { Manusia }\end{array}$ & $\begin{array}{l}\text { Indonesia wujud dan hidup untuk mewujudkan kasih sayang sesama } \\
\text { bangsa maupun antarbangsa, memantapkan ciri-ciri unik sebuah } \\
\text { masyarakat bangsa, yakni masyarakat bangsa yang sadar terhadap } \\
\text { tanggung jawab global, bersatu dalam mewujudkan persatuan universal }\end{array}$ \\
\hline $\begin{array}{l}\text { 2. Al-'Adalah } \\
\text { (keadilan) }\end{array}$ & $\begin{array}{l}\text { Keadilan sosial memimpin bangsa dan negara ke dalam } \\
\text { keadilan dan kebenaran sehingga semua rakyat Indonesia } \\
\text { mengetahuinya, melakukannya, dan hidup di dalamnya dan } \\
\text { mentaatinya }\end{array}$ \\
\hline $\begin{array}{l}\text { 3.-Musawah } \\
\text { (persamaan) }\end{array}$ & $\begin{array}{l}\text { Bahwa hidup dengan hukum dan peraturan adalah ciri masyarakat } \\
\text { berperadaban dan berkebudayaan. }\end{array}$ \\
\hline $\begin{array}{ll}\text { 4. } & \text { Karomah } \\
\text { insaniyah } \\
\text { (kehormatan) }\end{array}$ & Bahwa Manusia yang sempurna adalah yang adil dan beradab \\
\hline $\begin{array}{ll}\text { 5. } & \text { Tasamuh } \\
& \text { (Toleransi) }\end{array}$ & $\begin{array}{l}\text { Bahwa kemanusiaan yang adil dan beradab bermakna jujur, semangat } \\
\text { mempersiapkan generasi penerus, sadar akan keteraturan, menimbulkan } \\
\text { semangat universal yang mewujudkan sikap bahwa semua bangsa dapat } \\
\text { dan harus hidup dalam harmoni penuh toleransi dan damai, berbakti tanpa } \\
\text { mementingkan diri sendiri demi kebaikan bersama. }\end{array}$ \\
\hline $\begin{array}{l}\text { 6. Kerja sama } \\
\text { kemanusiaan }\end{array}$ & $\begin{array}{l}\text { Fitrah manusia yang interdependen, Bergerak membangun dalam wadah } \\
\text { negara }\end{array}$ \\
\hline
\end{tabular}

37 CH Robin Simanullang, Al-Zaytun Sumber Inspirasi, 158.

38 dutanews. February 9, 2019. https://www.doetaindonesia.com/persatuan-indonesia-terancamsyaykh-panji-ajak-kembali-ke-jatidiri-bangsa-yang-hakiki/, diakses pada tanggal 14 Januari 2019, jam 12:40. 


\begin{tabular}{|c|c|}
\hline $\begin{array}{l}\text { 7. Kebebasan, } \\
\text { kemerdekaan/ al- } \\
\text { Huriyah }\end{array}$ & $\begin{array}{l}\text { Bahwa kemerdekaan mewujudkan masyarakat yang beketuhanan, } \\
\text { yakni masyarakat yang anggotanya dijiwai oleh semangat mencapai ridlo } \\
\text { Tuhan (Mardlatillah), berbuat baik kepada seluruh manusia dan seluruh } \\
\text { mahluk. }\end{array}$ \\
\hline $\begin{array}{ll}\text { 8. } & \text { Perilaku } \\
\text { yang baik }\end{array}$ & $\begin{array}{l}\text { Bahwa mewujudkan masyarakat yang beketuhanan, yakni masyarakat } \\
\text { yang anggotanya dijiwai oleh semangat mencapai ridlo Tuhan } \\
\text { (Mardlatillah), berbuat baik kepada seluruh manusia dan seluruh mahluk. }\end{array}$ \\
\hline
\end{tabular}

Inilah dasar-dasar siyasah di dalam hubungan internasional atau siyasah dauliyah. Dasar-dasar tersebut semuanya mengacu kepada manusia sebagai satu kesatuan umat manusia, atau dengan kata lain dasar-dasar tersebut dalam rangka hifdzu al-Ummah dalam ruang lingkupnya yang paling luas yaitu seluruh manusia yang diikat oleh rasa ukhwah insaniyah.

Kesatuan ummat manusia, erat kaitannya dengan Bhinneka Tunggal Ika dalam pemikiran Syaykh Al-Zaytun A.S. Panji Gumilang. Kondisi bangsa yang beraneka ragam dan dinamis namun "Tunggal Ika", membuktikan bahwa kelanjutan masa depan Indonesia sebagai bangsa akan terus bergulir. Syaykh Al-Zaytun mengatakan, hanya dengan sikap memandang keberagaman dalam harmonilah, bangsa Indonesia akan dapat melampaui segala ramalan keretakan ${ }^{39}$. Seperti halnya pelangi, berbeda-beda namun tetap indah, harmoni, dan satu tujuan.

\section{KESIMPULAN}

Ideologi Pancasila menurut Syaykh Al-Zaytun A.S. Panji Gumilang merupakan ajaran Ilahi, yang harus diyakini oleh seluruh bangsa Indonesia, wajib ditaati dan menjadi ruh dalam kehidupan berbangsa dan bernegara. Dalam bingkai fiqh siyasah, pemikiran Syaykh Al-Zaytun A.S. Panji Gumilang terhadap Pancasila selaras dengan dasar-dasar siyasah daulah: kesatuan umat manusia, al-'adalah (keadilan), al-musawah (persamaan), karomah insaniyah (kehormatan manusia), tasamuh (toleransi), kerjasama kemanusiaan, al-huriyah (kebebasan/kemerdekaan), ahlaq al-karimah (perilaku moral yang baik). Universalnya nilai-nilai Pancasila dibuktikan dengan keberadaannya dalam siyasah daulah. Bangsa Indonesia seharusnya bangga terhadap Pancasila sebab nilai-nilai yang tercantum dalam Pancasila bersifat universal. Kebanggaan seluruh elemen bangsa Indonesia terhadap Ideologi Pancasila dibuktikan dengan ketaatan dan menjadikannya ruh dalam kehidupan berbangsa dan bernegara.

\section{REFERENSI:}

Buku:

Abbas, Ahmad Sudirman, Figh Siyasah, Depok: Abbas Press, 2015.

\footnotetext{
${ }^{39} \mathrm{CH}$ Robin Simanullang, Al-Zaytun Sumber Inspirasi, 133.
} 
Al-Anshori, Abdul Ghofar, Penerapan Prinsip Syari'ah dalam Lembaga Pembiayaan dan Perusahaan Pembiayaan, Yogyakarta: Pustaka Pelajar, 2008.

Athiyat, Ahmad, Jalan Baru Islam: Studi Tentang Transformasi dan Kebangkitan Umat, Bogor: Pustaka Thariqul Izzah, 2004.

Darmodihardjo, D., Orientasi Singkat Pancasila, Jakarta: Gita Karya, 1978.

Ibnu Syarif, Muzar \& Zada, Khamami, Figh Siyasah, Jakarta: Erlangga, 2008.

Kaelan, Negara Kebangsaan Pancasila: Kultural, Historis, Filosofis, Yuridis dan Aktualisasinya, Yogyakarta: Paradigma, 2013.

Kaelan, Pendidikan Pancasila, Yogyakarta: Paradigma, 2000.

Khallaf, Abd al-Wahhab, Al-siyasah al-Syar'iyah wa al-Figh al-Islam, Mesir: Dar al Anshar, 1997.

Latif, Yudi., Negara Kebangsaan Pancasila: Kultural, Historis, Filosofis, Yuridis dan Aktualisasinya, Yogyakarta: Paradigma, 2013.

Latif, Yudi, Negara Paripurna: Historisitas, Rasionalitas dan Aktualitas Pancasila, Jakarta: PT. Gramedia Pustaka Utama, 2011.

Manzhur, Ibn, Lisan al-'Arab, Beirut: Dar El-Shadir, 1986.

Muhajir, Noeng, Metode Penelitian Kualitatif, Yogyakarta: Rake Paskin, 1996.

Simanullang, CH Robin, Al-Zaytun Sumber Inspirasi, Jakarta: Pustaka Tokoh Indonesia, 2015.

Soekarno, Pancasila sebagai Dasar Negara, Jakarta: Inti Idayu Press dan Yayasan Pendidikan Soekarno, 1984.

Subandi, AL Marsudi, Pancasila dan UUD 45 dalam Paradigma Reformasi, Jakarta: PT. Raja Grafindo Persada, 2001.

Sukardja, Ahmad, Hukum Tata Negara \& Hukum Administrasi Negara Dalam perspektif Fiqh Siyasah, Jakarta: Sinar Grafika, 2012.

Suseno, Franz Magnis, Filsafat Sebagai Ilmu Kritis, Yogyakarta: Kanisius, 1992.

Suwarno, Pancasila Budaya dan Bangsa, Yogyakarta: Kanisius, 1993.

Syuhud, A Fatih, Menuju Kebangkitan Islam dengan Pendidikan, Pustaka Al-Khoirot, 2012.

Taj, Abdurrahman, Al Siyasah al-Syar'iyah wa al-Figh al-Islami, Mesir: mathbaa'ah Dar alTa'lif, 1987.

\section{Internet:}

Detikcom.

"detiknews." detik.com.

April

28,

2011. https://m.detik.com/news/berita/d1627505/imam-nii-kw-9-panji-gumilangngumpet-karena-sudah-nikmati-hidup.

dutanews. February 9, 2019. https://www.doetaindonesia.com/persatuan-indonesiaterancam-syaykh-panji-ajak-kembali-ke-jatidiri-bangsa-yang-hakiki/. 